\title{
Economic costs of biological invasions in Asia
}

\author{
Chunlong Liu' ${ }^{1,2,3,4}$, Christophe Diagne ${ }^{4}$, Elena Angulo ${ }^{4}$, Achyut-Kumar Banerjee, \\ Yifeng Chen ${ }^{6}$, Ross N. Cuthbert ${ }^{7}$, Phillip J. Haubrock ${ }^{8,9}$, Natalia Kirichenko ${ }^{10,11,12}$, \\ Zarah Pattison $^{13}$, Yuya Watari ${ }^{14}$, Wen Xiong ${ }^{15}$, Franck Courchamp ${ }^{4}$
}

I Institute of Biology, Freie Universität Berlin, Berlin, Germany 2 Leibniz Institute of Freshwater Ecology and Inland Fisheries (IGB), Berlin, Germany 3 Berlin-Brandenburg Institute of Advanced Biodiversity Research (BBIB), Berlin, Germany 4 Université Paris-Saclay, CNRS, AgroParisTech, Ecologie Systématique Evolution, Orsay, France 5 School of Life Sciences, Sun Yat-sen University, Guangzhou, China 6 Laboratory of biological invasion and adaptive evolution, Institute of Hydrobiology, Chinese Academy of Sciences, Wuhan, China 7 GEOMAR Helmholtz-Zentrum für Ozeanforschung Kiel, Kiel, Germany 8 Senckenberg Research Institute and Natural History Museum Frankfurt, Department of River Ecology and Conservation, Gelnhausen, Germany 9 University of South Bohemia in České Budèjovice, Faculty of Fisheries and Protection of Waters, South Bohemian Research Center of Aquaculture and Biodiversity of Hydrocenoses, Vodñany, Czech Republic 10 Sukachev Institute of Forest, Siberian Branch of Russian Academy of Sciences, Federal Research Center "Krasnoyarsk Science Center SB RAS", Krasnoyarsk, Russia I I Siberian Federal University, Krasnoyark, Russia 12 Reshetnev Siberian State University of Science and Technology, Krasnoyarsk, Russia 13 School of Natural and Environmental Sciences, Modelling, Evidence and Policy Group, Newcastle University, Newcastle Upon Tyne, UK $\mathbf{I} \mathbf{4}$ Forestry and Forest Products Research Institute, 1 Matsunosato, Tsukuba-shi, Ibaraki, Japan 15 College of Fisheries, Guangdong Ocean University, Zhanjiang, China

Corresponding author: Chunlong Liu (liuchunlong113@gmail.com)

Academic editor: R. Zenni | Received 30 August 2020 | Accepted 3 February 2021 | Published 29 July 2021

Citation: Liu C, Diagne C, Angulo E, Banerjee A-K, Chen Y, Cuthbert RN, Haubrock PJ, Kirichenko N, Pattison Z, Watari Y, Xiong W, Courchamp F (2021) Economic costs of biological invasions in Asia. In: Zenni RD, McDermott S, García-Berthou E, Essl F (Eds) The economic costs of biological invasions around the world. NeoBiota 67: 53-78. https://doi.org/10.3897/neobiota.67.58147

\begin{abstract}
Invasive species have caused severe impacts on biodiversity and human society. Although the estimation of environmental impacts caused by invasive species has increased in recent years, economic losses associated with biological invasions are only sporadically estimated in space and time. In this study, we synthesized the losses incurred by invasions in Asia, based on the most comprehensive database of economic costs of invasive species worldwide, including 560 cost records for 88 invasive species in 22 countries. We also assessed the differences in economic costs across taxonomic groups, geographical regions and impacted sectors, and further identified the major gaps of current knowledge in Asia. Reported
\end{abstract}

Copyright Chunlong Liu et al. This is an open access article distributed under the terms of the Creative Commons Attribution License (CC BY 4.0), which permits unrestricted use, distribution, and reproduction in any medium, provided the original author and source are credited. 
economic costs of biological invasions were estimated between 1965 and 2017, and reached a total of US\$ 432.6 billion (2017 value), with dramatic increases in 2000-2002 and in 2004. The highest costs were recorded for terrestrial ectotherms, for species estimated in South Asia, and for species estimated at the country level, and were related to more than one impacted sector. Two taxonomic groups with the highest reported costs were insects and mammals, and two countries with the highest costs were India and China. Non-English data covered all of 12 taxonomic groups, whereas English data only covered six groups, highlighting the importance of considering data from non-English sources to have a more comprehensive estimation of economic costs associated with biological invasions. However, we found that the estimation of economic costs was lacking for most Asian countries and for more than $96 \%$ of introduced species in Asia. Further, the estimation is heavily biased towards insects and mammals and is very limited concerning expenditures on invasion management. To optimize the allocation of limited resources, there is an important need to better and more widely study the economic costs of invasive alien species. In this way, improved cost reporting and more collaborations between scientists and stakeholders are needed across Asia.

\section{Abstract in Chinese}

生物入侵在亚洲造成的经济损失. 生物入侵已经造成了严重的生态和经济影响。虽 然关于生物入侵生态影响的研究在近年来不断增加, 但是生物入侵的经济 影响却仅见于零星的研究中。在本研究中, 我们整合了当前报道的生物入 侵在亚洲造成经济损失的数据, 共包含 22 个国家的 88 种入侵生物的 560 条数 据。我们进一步分析了经济损失在不同类群、区域以及部门之间的差异， 并提出了未来函待解决的相关问题。在亚洲，生物入侵经济损失的数据报 道的时间范围为1965至2017年。经济损失的总量达到了4326亿美元，且 在2000 - 2002以及 2004 年发生了较大幅度的增长。经济损失在陆生变温动 物、南亚以及国家尺度上最高, 且主要的经济损失与超过一个部门相关。 经济损失最高的两个类群为昆虫及哺乳动物、而最高的两个国家为印度和 中国。非英语数据涵盖了数据中所有的 12 个类群，但是英语数据只涵盖了 6 个类群, 这一结果揭示了考虑非英语数据对综合地评估生物入侵经济损失 的重要性。然而, 我们也发现大多数亚洲国家都缺乏生物入侵造成经济损 失的数据，且目前仅有不足 $4 \%$ 的外来种有经济损失数据。此外，经济损失 的评估显著偏向于昆虫和哺乳动物, 严重影响着生物入侵的管理。为了优 化生物入侵的管理, 需要更加全面且广泛地评估入侵生物所造成的经济损 失。这需要亚洲的研究人员和管理人员之间的更加广泛的合作。

\section{Abstract in French}

Coûts économiques des invasions biologiques en Asie. Les espèces exotiques envahissantes ont de graves répercussions sur la biodiversité et les sociétés humaines. Bien que l'estimation des impacts environnementaux causés par ces espèces a augmenté ces dernières années, les pertes économiques associées aux invasions biologiques ne sont estimées que sporadiquement dans l'espace et le temps. Dans cette étude, nous présentons la synthèse des pertes économiques associées aux invasions biologiques en Asie, en nous appuyant sur la base de données la plus complète sur les coûts économiques des espèces exotiques envahissantes dans le monde, comprenant 560 rapports de coûts pour 88 espèces exotiques envahissantes dans 22 pays d'Asie. Nous avons également évalué les différences de coûts économiques entre les groupes taxonomiques des espèces exotiques envahissantes, les régions géographiques et les secteurs touchés, et nous avons identifié les principales lacunes des connaissances actuelles en Asie. Les coûts économiques déclarés des invasions biologiques ont été estimés entre 1965 et 2017 et ont 
atteint un total de 432.6 milliards de dollars (valeur de 2017), avec des augmentations spectaculaires en 2000-2002 et en 2004. Les coûts les plus élevés ont été enregistrés pour les ectothermes terrestres, pour les espèces estimées en Asie du Sud et pour les espèces estimées au niveau des pays, et étaient liés à plus d'un secteur impacté. Les insectes et les mammifères sont les deux groupes taxonomiques dont les coûts déclarés étaient les plus élevés, les deux pays où les coûts étaient les plus élevés étant l'Inde et la Chine. Les données en langue non anglaise couvraient l'ensemble des 12 groupes taxonomiques étudiés, tandis que les données en anglais ne couvraient que six groupes, ce qui souligne l'importance de tenir compte des données provenant de sources non non reportés en anglais pour avoir une estimation plus complète des coûts économiques associés aux invasions biologiques. Cependant, nous avons constaté que l'estimation des coûts économiques est insuffisante pour la plupart des pays asiatiques et pour plus de 96\% des espèces introduites en Asie. De plus, elle est fortement biaisée envers les insectes et les mammifères et est très limitée en ce qui concerne les dépenses pour la gestion des invasions. Pour optimiser l'allocation des ressources limitées, il est important d'étudier de façon plus vaste et plus approfondie les coûts économiques des espèces exotiques envahissantes. Également, il faut améliorer la standardisation des études sur les coûts et accroître la collaboration entre les scientifiques et les porteurs d'enjeu en Asie.

\section{Abstract in Japanese}

アジアにおける外来種の侵入に伴う経済コスト. 外来種は生物多様性や人間社会 に深刻な影響を与えている。近年，侵略的外来種による環境への影響評 価は数多くなされてきたが，外来種の侵入に伴う経済的損失の推定は， 地理的, 時期的に散発的にしか行われてこなかった。本研究では, 22 力 国，88種の外来種の経済コス卜記録560件を含む，世界で最も包括的な 外来種の経済コストデータベースをもとに，アジアにおける外来種の侵 入による経済コストを集計した。また，分類群，地域，コスト区分間で の経済コストの違いを評価し，現時点でのアジアにおける知見の主要な ギャップを明らかにした。アジアにおける外来種の侵入の経済コスト は，1965年から 2017年の期間の推定值が報告されており，計4, 326億米ド ル（2017年の価值）に達し，特に2000年から2002年と2004年には劇的に 増加していた。最も高いコストが記録されたのは，陸生の外温動物，南 アジアでコストが生じている種, 国家スケールでコストが生じている種 であった。これらは2つ以上のコスト区分に関連していた。報告されたコ ストが最も高かった分類群は昆虫類と哺乳類であった。最も高いコスト が推定された国は，インドと中国であった。非英語言語のデータソース から推定されたコストは12の分類群すべてをカバーしていたのに対し， 英語のデータソースは6つの分類群しかカバーしていなかったことから， 外来種の侵入による経済的コストを網羅的に推定するためには，英語以 外の言語の情報を考慮することが重要であることがわかった。しかしな がら，経済コストの推定は，アジアのほとんどの国において，またアジ アの外来種の $96 \%$ 以上において，不足している状況であることがわかっ た。さらに，経済コストの報告は昆虫類や哺乳類に大きく偏っており， また, 外来種管理のための経済支出についての情報は非常に限られてい た。限られた経済的，人的資源の配分を最適化するためには，外来種の 侵入に関する経済的コストをょり的確に, より広範に調査する必要があ る。このように, アジア全域において, 経済コストのよりょい報告体制 と, 科学者とステークホルダーとのより緊密な連携が必要とされている。 


\section{Abstract in Russian}

Экономические потери от биологических инвазий в Азии. Инвазионные виды оказывают серьезное воздействие на биоразнообразие и человеческое общество. Несмотря на то, что в последние годы воздействие инвазионных организмов на окружающую среду заметно выросло, экономические потери, связанные с биологическими инвазиями, оцениваются все еще редко. Используя количественные Аанные из наиболее полной мировой базы данных экономических ущербов от инвазионных видов, мы проанализировали сведения об экономических потерях в результате биологических инвазий в Азии: Аанные насчитывали 560 позиций убытков Аля 88 инвазионных видов в 22 азиатских странах. Мы также оценили размер экономических потерь в разных таксономических группах инвайдеров, географических регионах и секторах экономики, и кроме того, определили основные пробелы в знаниях о потерях от биологических инвазий в Азии. В 1965-2017 гг. экономические потери от инвайдеров составили около 432.6 млрА Аолмаров США (по курсу валюты на 2017 г.) с резким увеличением убытков в 2000-2002 гг. и в 2004 г. Наиболее высокие траты были связаны с наземными инвазионными холоднокровными организмами как в Южной Азии в целом, так и в ее отдельных странах и отмечались в более чем одном экономическом секторе. Аве таксономические группы - насекомые и млекопитающие - обусловили самые высокие экономические потери; наибольший экономический ущерб от них был отмечен в двух странах - Индии и Китае. Аанные по экономическим потерям из неанглоязычных (т.е. местных) митературных источников касались всех 12 таксономических групп, тогда как данные из англоязычной митературы по Азии охватывали только шесть групп, что говорит о важности учетов Аанных из национальных источников Аля более полной оценки экономических потерь от инвазий. Мы отметили, что оценки экономических потерь от инвазий отсутствуют в большинстве азиатских стран; до сих пор потери не оценивались Аля 96\% видов, интродуцированных в Азию. Имеющиеся Аанные, преимущественно связанные с инвазиями насекомых и млекопитающих, указывают на низкие расходы на мониторинг чужеродных видов. Существует большая потребность в более тщательных оценках экономических ущербов от инвазий чужеродных видов в разных регионах Азии. Таким образом, статья призывает к улучшению отчетности по экономическим потерям от инвазий и расширению сотрудничества межАу учеными и заинтересованными сторонами в Азии.

\section{Abstract in Spanish}

Los costos económicos de las invasiones biológicas en Asia. Las invasiones biológicas han causado serios impactos en la biodiversidad y en las sociedades humanas. Aunque las estimaciones de los impactos ambientales causados por las especies invasoras han aumentado en los últimos años, las pérdidas económicas asociadas han sido estimadas esporádicamente tanto espacialmente como temporalmente. En este estudio sintetizamos las pérdidas económicas producidas por las invasiones biológicas en Asia, basándonos en la base de datos más exhaustiva sobre los costos económicos de las especies invasoras que existe a nivel mundial, incluyendo 560 entradas de costos para 88 especies invasoras en 22 países. También evaluamos las diferencias en los costos económicos entre grupos taxonómicos, entre regiones geográficas y entre sectores económicos impactados, e identificamos las lagunas del conocimiento actual en Asia. Los costos económicos reportados para las invasiones biológicas fueron estimados entre 1965 y 2017, y alcanzaron un total de 432.6 mil millones de dólares americanos (valor de 2017), incrementando dramáticamente en el período 2000-2002 y en 2004. Los costos más altos fueron reportados para los ectotermos terrestres, para especies reportadas en el sur de Asia, para especies estimadas a nivel de país, y estuvieron relacionados con más de un sector económico. Los mayores costos reportados fueron para los insectos y los mamíferos (en cuanto a grupos taxonómicos), y para India y China (en cuanto a países). Los datos obtenidos a partir de documentos no ingleses cubrieron los 12 grupos taxonómicos reportados, mientras que los documentos 
en inglés solo cubrieron 6 grupos, poniendo de manifiesto la importancia de considerar los documentos no ingleses para tener una estimación más exhaustiva de los costes económicos asociados a las invasiones biológicas. A pesar de ello, encontramos que hay una falta de estimaciones económicas para la mayoría de los países Asiáticos y para más del 96\% de las especies introducidas en Asia. Más aún, las estimaciones reportadas están sesgadas hacia insectos y mamíferos y muy limitadas en cuanto a los gastos en el manejo de las invasiones. Para optimizar el reparto de los recursos limitados que existen, es muy importante estudiar mejor y más ampliamente los costos económicos de las especies invasoras. Por lo tanto, es necesario el aumento de los informes sobre costos y las colaboraciones entre científicos y gestores en Asia.

\section{Keywords}

Economic damages, InvaCost, invasive alien species, monetary losses, non-English data, non-native species

\section{Introduction}

Biological invasions are one of the most serious threats to biodiversity and human society (Vander Zanden and Olden 2008; Seebens et al. 2018). With increasing anthropogenic activities, thousands of species have been introduced across the globe, causing substantial impacts on ecosystem service and social welfare (Essl et al. 2011; Bradshaw et al. 2016; Hanley and Roberts 2019). To better understand invasion impacts and develop cost-effective management strategies, recent years have seen remarkable increases in the estimation of environmental impacts caused by invasive species (i.e. alien species that have caused impacts on the economy and environment in new ranges) (Lodge et al. 2016; McGeoch et al. 2016). At the global scale, environmental impacts have been estimated for different taxonomic groups, including invasive plants (Vilà et al. 2011), amphibians (Nunes et al. 2019), crayfish (Twardochleb et al. 2013), and marine species (Anton et al. 2019). However, the estimation of their economic impacts lags behind and is still in its infancy (Lodge et al. 2016). Despite the crucial importance for informing invasion management (Aukema et al. 2011; Diagne et al. 2020a), economic impacts of invasive species have only been estimated for certain taxa (e.g. insects; Bradshaw et al. 2016), countries (e.g. China; Xu et al. 2006), regions (e.g. Southeast Asia; Nghiem et al. 2013), or sectors (e.g. agriculture; Paini et al. 2016). Estimating economic impacts is further hampered by the difficulty of compiling a comprehensive list of invasive species (Wilson et al. 2018), and the uncertainty associated with the methods applied for estimation (Bradshaw et al. 2016; Cuthbert et al. 2020). To date, systematic estimation of economic impacts is lacking for most species and regions, limiting our ability to manage biological invasions at a broad scale (Diagne et al. 2020a).

Asia is among the continents suffering most from biological invasions (Pimentel et al. 2001; Ding et al. 2008; Shepard et al. 2013). As the continent with the largest human population and fastest economic growth (International Monetary Fund 2019; https://www.imf.org/), Asia has become a key recipient area for invasive species (Turbelin et al. 2017). Expanding trading activities in Asian countries not only accelerate the introduction of species, but also exacerbate invasion-induced economic impacts 
(Nghiem et al. 2013; Seebens et al. 2017). Sardain et al. (2019) reported that China's share of maritime transportations increased from $1.4 \%$ in 1990 to $20.1 \%$ in 2013 , and that Northeast Asia would become the global hotspot of marine invaders in the near future. Paini et al. (2016) predicted that China would suffer the highest economic loss in agriculture from invasive pests worldwide. Many species are also intentionally introduced to increase food production and mitigate environmental impacts (Ding et al. 2008; Wang et al. 2020), or are released for religious purposes (Liu et al. 2012). Asia is the leading continent for aquaculture, with a number of species being introduced for aquaculture practices. But many of them have escaped from facilities and successfully established in the wild (Liu et al. 2017; Ju et al. 2019). In East and Southeast Asia, Buddhist and Taoist practices regularly result in the intentional release of captive alien animals, such as American bullfrogs Lithobates catesbeianus and common carp Cyprinus carpio, to gain spiritual merit (Liu et al. 2012; Xiong et al. 2015). These species not only cause widespread environmental problems, but also are recognized as a great threat to economic development (Ding et al. 2008; Seebens et al. 2017).

Despite lacking information at the continental scale, economic impacts of invasive species have been estimated in different countries and regions in Asia. In Southeast Asia, Nghiem et al. (2013) reported that the annual economic loss in agriculture, environment and public health accounted for an estimated US\$33.5 billion. Xu et al. (2006) mentioned that economic loss in China was US\$14.5 billion in the year 2000 , which approximately accounted for $1.36 \%$ of China's annual GDP. A more striking case is India, in which invasive weeds were estimated to incur a 30\% loss in crop yields, with extrapolated annual economic loss of US\$ 91 billion (Pimentel et al. 2001). Economic costs can also be markedly high for individual invasive species. For example, yellow fever mosquito Aedes aegypti is reported to cause an annual economic burden of US\$ 950 million in 12 countries in Southeast Asia alone, due to its capacity of rapidly transmitting the dengue virus (Shepard et al. 2013). Although these pioneering studies provide useful information, their findings are spatially and temporally sporadic, thus preventing a comprehensive understanding of ongoing economic impacts of invasive species.

Language is another barrier impeding the synthesis of economic impacts across Asian countries. While English dominates current scientific activities (Amano et al. 2016; Tao et al. 2018), it is not the mother tongue in most Asian countries, whereas economic costs of invasions are often reported in grey literature (e.g. government reports and graduate school theses) written in national languages (Hanley and Roberts 2019). Moreover, studies published in non-English languages (e.g. Chinese and Japanese) are substantial (Tao et al. 2018; Konno et al. 2020), suggesting that data of economic impacts from non-English sources might be abundant. In the field of biodiversity conservation, Amano et al. (2016) found that more than one third of scientific studies were published in non-English languages. Language, thus, acts as a hurdle in accessibility and searchability when compiling data of economic impacts in Asia. To account for information gaps of cost estimation due to language barriers, it is, therefore, important to consider studies published in non-English languages. 
In this study, we used the most comprehensive database of economic costs of invasive species worldwide (InvaCost; Diagne et al. 2020b) to understand the damages invasive species have caused to the Asian economy. Specifically, we aimed to address three overarching questions: (1) what are the costs and expenditures of invasions in Asia, and how do they change over time; (2) what are the differences in economic costs across taxonomic groups, geographical regions and impacted sectors, and (3) what are the major gaps in current knowledge on invasion costs in Asia across languages, taxonomic groups, geographical regions, and impacted sectors?

\section{Methods}

\section{Data compilation}

The dataset of economic costs caused by invasive species in Asia was compiled from the original version of the InvaCost database (Diagne et al. 2020b), which was supplemented with data from non-English documents searched in Chinese, Japanese, Russian, and Indian languages (Angulo et al. 2021; data accessible at: https://doi.org/10.6084/ $\mathrm{m} 9$.figshare.12928136). Economic costs of all records were standardized in US dollar (2017 value). In this study, we selected economic costs solely estimated in Asia, and thus excluded those covering other continent(s). We specifically focused on economic impacts that actually occurred, and excluded costs estimated based on computational modelling and predictions beyond the spatial and/or temporal extents in which species currently exist. To refine recorded information, we carefully checked the data to correct potential mistakes and remove overlaps (i.e. cost records included in another record with larger spatial scale or longer temporal scale) and duplicates (i.e. costs records with the same descriptors were reported by two different sources). Xu et al. (2006) is the only study for which the data are available in both English and Chinese. We only kept the Chinese data which were reported species by species, whereas English data only provided aggregated estimates by ecological groups and impacted sectors. Similarly, a cost for an eradication project of invasive fruit flies was reported in English and Japanese. The latter was kept, as it described the costs with more details (Watari et al. 2021). The final dataset used in this study is provided as a supplementary material (Suppl. material 1: Table S1).

Species were classified into 12 taxa belonging to five ecological groups: aquatic species (crustaceans, fishes, and molluscs), microorganisms (bacteria, fungi, and viruses), plants, terrestrial ectotherms (insects, amphibians and reptiles), and terrestrial endotherms (birds and mammals). In the study, for simplicity, we listed viruses among microorganisms, despite not being cellular. Costs estimated for multiple species belonging to more than one ecological group were labeled as "Unspecified". Countries were classified into four geographical regions: East Asia, South Asia, Southeast Asia, and Western Asia, following the classification in United Nations Statistics Division (https://unstats.un.org/unsd/methodology/m49/). Our dataset did not include records from Central Asia and North Asia (see Results for more details). Spatial scales of 
costs were classified into three categories: region-level (i.e. costs estimated across more than one country), country-level, and site-level (i.e. costs estimated within one country subdivision). We further re-assigned costs into seven impacted sectors: agriculture, authorities, environment, fishery, forestry, health, and social welfare (Suppl. material 2: Table S2), and four types of cost: damage, management, knowledge, and damage \& management (Suppl. material 3: Table S3). Costs that could not be assigned to one specific sector were labeled as "Multiple". Cost data were further identified as being of low or high reliability based on the source of the data. Specifically, data were considered of high reliability if they were reported from sources validated by experts, including peer-reviewed articles and official documents; otherwise, data were considered to be of low reliability. InvaCost did not determine data reliability specifically based on the approaches applied to estimate costs, because approaches were quite heterogenous among sources.

\section{Data analyses}

The temporal trends of cost estimation were assessed based on the changes in the number of species and cumulated economic costs, for the five ecological groups, for four geographical regions, and for three spatial scales, respectively. Costs labeled with "Unspecified" were excluded from the assessment for ecological groups, and costs covering more than one geographical region were excluded from the assessment for geographical regions.

We then assessed the compositions of species that have been estimated for economic costs in Asia, and the compositions of the total amount of economic costs among different taxonomic groups and countries, respectively. We also assessed the compositions of species that have been introduced in Asia for comparison. Costs estimated for multiple taxa and/or labeled with "Unspecified" were excluded from the assessment for the composition of taxonomic groups. All above analyses were performed using English and non-English data separately to better understand the specific contributions of reporting languages. For 22 countries included in the study (see Results for more details), ten countries only included data of $A$. aegypti. We therefore excluded these countries from the assessment of species composition among countries. To assess the difference in compositions of species already introduced in Asia and species estimated for economic impacts, we collected the data of species that have been introduced in Asia (i.e. introduced species) (see Results for more details) from the Global Alien Species First Records Database (Seebens et al. 2018, accessed in June 2020). To assess the completeness of cost estimation among groups and countries, we calculated the proportion of species being estimated for economic impacts and species being introduced for each of five ecological groups per country. We also assessed the variations in the number of cost records and economic costs among impacted sectors and types of cost. Last, we identified invasive species that were introduced in Asia but were only reported with economic costs in other continents (i.e. outside of Asia) using data from InvaCost database. All analyses were conducted in R software (v 3.5.0.) (R Development Core Team 2018). 


\section{Results}

\section{Data summary}

Our dataset included 560 cost records for 88 invasive species, with the total economic loss reaching US\$ 432.6 billion (Table 1). The economic costs captured within this dataset range between 1965 and 2017, with substantially less cost recorded in the $20^{\text {th }}$ century (US\$ 64.4 billion) than in the $21^{\text {th }}$ century (US\$ 368.2 billion) (Suppl. material 1: Table S1). Instead of increasing steadily over time, the number of species for which costs were estimated showed spikes in 2000 (36 species) and in 2013-2016 (58 species) (Fig. 1a), which were driven by the inclusion of Chinese data (26 species)
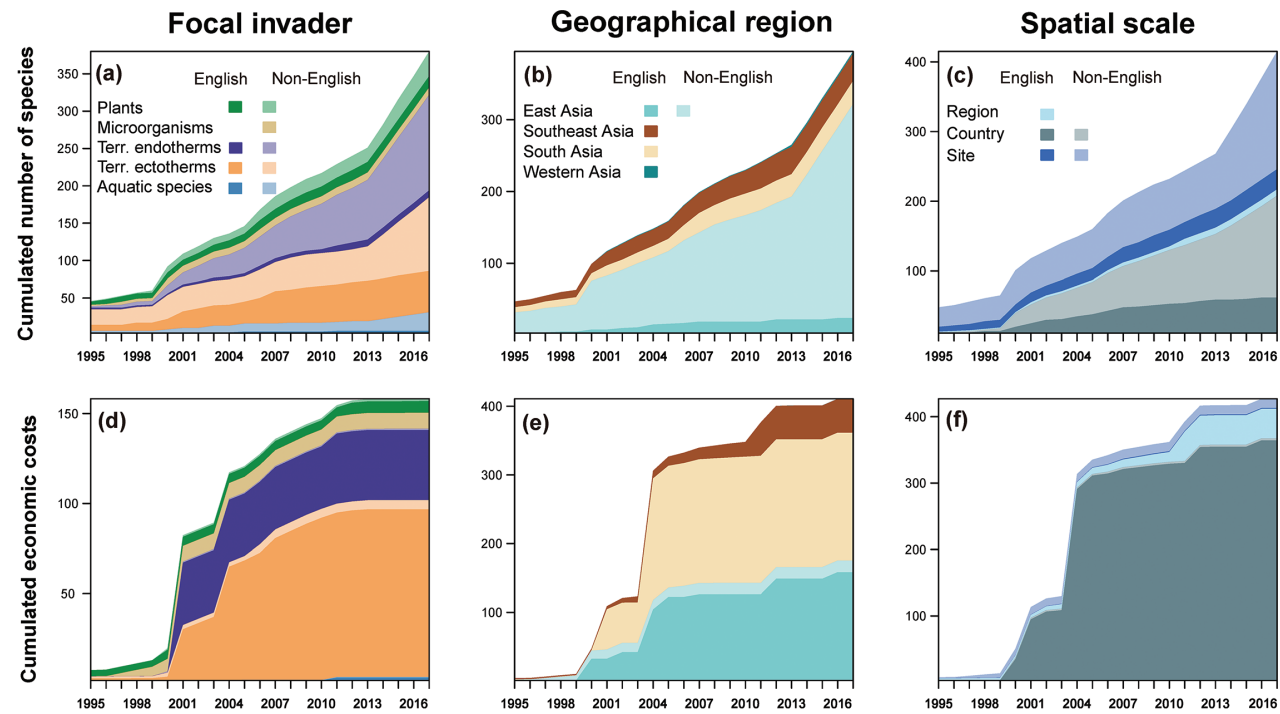

Figure I. The temporal trends in the cumulated number of species and the amount of economic costs between 1995 and 2017. Focal invaders are classified into: Plants, Microorganisms, Terrestrial endotherms, Terrestrial ectotherms, and Aquatic species. Geographical regions are classified into: East Asia, Southeast Asia, South Asia, and Western Asia. Spatial scales are classified into: Region, Country, and Site. Economic costs are standardized in US billion dollars (2017 value). Note that the contribution of each group at a point in time is represented by the proportionate height width (not the absolute height) of the corresponding color at that particular year. Given some cost data cannot be classified into specific groups of invaders or geographical regions, the number of species and economic costs are different between panels. One species can be estimated in different years and/or different publications. The temporal scale is set since 1995, because economic costs are rarely estimated between 1965 and 1995 (see Results for more details).

Table I. Data of economic costs of invasive species compiled from English and non-English studies. Economic costs are standardized in US dollar (2017 value).

\begin{tabular}{lccccc}
\hline \multicolumn{1}{c}{ Language } & Temporal range & Number of countries & Number of species & Number of records & Economic costs (US\$) \\
\hline English & $1976-2017$ & 22 & 21 & 140 & 415.3 billion \\
Non-English & $1965-2017$ & 2 & 74 & 421 & 17.3 billion \\
\hline
\end{tabular}


and Japanese data (48 species), respectively (Suppl. material 1: Table S1). Dramatic increases in economic cost occurred in 2000-2002 (US\$ 137.4 billion) and in 2004 (US\$ 180.3 billion) (Fig. 1d), driven by a few records of high economic cost in China and India, respectively (Suppl. material 1: Table S1). Twenty-two countries reported economic costs; however, nine of these countries only had one record each. Japan had the highest number of records (326); retrieved primarily from non-English studies (99.7\%). Among species, economic costs of $A$. aegypti were estimated in the highest number of countries (15), whereas costs of 80 species were only recorded in only one country. Economic costs were markedly different among species: the mosquito $A$. aegypti incurred the highest cost (US\$ 44.6 billion) and the whitetop weed Parthenium hysterophorus caused the lowest cost (US\$34.0).

We found marked differences in the number of species and records, and total amount of economic costs between English and non-English data (Table 1). English data covered all of the 22 countries included in the dataset, but the number of species was only $28.4 \%$ of the non-English data, which was consisted only of data from China and Japan; all data retrieved in Russian was for the European part of the country and not used here, no data were returned using either of four Indian languages (Hindi, Telugu, Tamil, and Bengali), and other Asiatic languages were not searched. More strikingly, one species (A. aegypti) contributed to $47.9 \%$ of the English records, and there were only seven species included in both English and non-English data. The costs from non-English data tended to be more numerous and smaller (Table 1). Despite the number of English records being around one third (33.3\%) of that of non-English records, the total cost from English references was 24 times higher than that from non-English references. The proportion of records with high reliability was marginally greater for non-English (91.2\%) than English data (82.7\%), but both were very high. Most of the English records were estimated at country level (65.5\%), compared to the majority of records being at site level (56.8\%) for non-English data. In addition, we found that $23.8 \%$ of species in the English data were among 100 of the world's worst invasive alien species (Global Invasive Species Database; http://www.iucngisd.org/gisd/100_worst.php), and the proportion in non-English data was only $13.5 \%$.

\section{Taxonomic compositions}

There are clear differences in the number of species and the total economic costs reported among five ecological groups (Fig. 1a, d). In our dataset, the highest number of species $(40.5 \%)$ belonged to terrestrial ectotherms, followed by terrestrial endotherms (36.1\%), aquatic species (8.2\%), plants (6.6\%), and microorganisms (2.6\%) (Fig. 1a). Surprisingly, only around one third of the total economic costs (US\$ 158.2 billion) was attributed to particular species, with most costs (63.4\%) being recorded for multiple species (Fig. 1d). Terrestrial ectotherms reportedly caused the highest costs (US\$ 98.2 billion), followed by terrestrial endotherms (US\$ 39.7 billion); whereas aquatic species caused the lowest costs (US\$ 3.6 billion) (Fig. 1d). Economic costs estimated from English data were much higher than records from non-English data for terrestrial ectotherms (18.0 times), terrestrial endotherms (51.8 times), aquatic species (10.6 times), 
and plants (5.1 times). For marine invaders, our dataset only included two records related to the red tide (i.e. vast concentrations of aquatic single-celled microorganisms, such as protozoans and diatom algae) and one record related to jellyfish invasion.

The completeness of cost estimations was low across countries (Suppl. material 4: Table S4). China was the only country with cost estimation for all of five ecological groups, whereas seven countries only had cost estimation for one group. Microorganisms were the group for which the costs were estimated in most countries $(N=10)$, whereas the cost of terrestrial endotherms was only estimated in four countries.

The compositions of species introduced in Asia, as well as the invasive alien species for which costs were estimated, and the proportions of economic costs that they have caused were not evenly distributed among taxonomic groups (Fig. 2). For 2,703 species introduced in Asia, plants constituted the group with the highest proportion of introduced species (44\%), followed by insects $(13.2 \%)$, birds $(11.5 \%)$, and fishes $(10.4 \%)$ (Fig. 2a). The 88 species estimated for economic costs only accounted for $3.3 \%$ of all introduced species.

The two groups having the most species with cost estimates were insects (34.2\%) and mammals (29.3\%) (Fig. 2b), despite their relatively small contributions to the number of introduced species. The other three groups contributing the most introduced species (plants, birds and fishes) were relatively less estimated in terms of cost. The taxonomic differences in amounts of economic costs were also pronounced (Fig. 2c): insects and mammals caused more than $80 \%$ of the total losses $(48.9 \%$ and $33.2 \%$, respectively), while seven out of 12 taxa contributed to $<1 \%$ of the total losses, including amphibians, bacteria, birds, crustaceans, fishes, fungi, and reptiles. We also found that non-English data covered all these 12 taxonomic groups, whereas English data only covered six groups (Fig. 2c). The amount of economic costs showed remarkable variations among species. For example, Rattus spp. caused a loss of US\$ 34.6 billion in social welfare and $A$. aegypti caused US\$ 44.2 billion to the health system. Social welfare and health system were two sectors suffering the greatest economic losses from particular species (US\$ 68.3 billion; Fig. 3), which were mainly caused by mammals and insects. Most costs were related to damages caused by invasive species (US\$ 91.2 billion), which were reported in East Asia, South Asia and Southeast Asia (Fig. 3).

There were 135 species introduced in Asia for which economic costs were reported in other continents (no reported economic cost in Asia yet) (Suppl. material 5: Table S5). The total amount of their costs outside of Asia reached US\$ 126.1 billion. Among seven species with the highest costs, there were six insect species, with the Asian long-horned beetle Anoplophora glabripennis (native in China and invasive in Europe, North America and other parts of Asia) causing the highest economic cost (US\$ 5.84 billion).

\section{Geographical compositions}

The number of species and total economic costs also substantially differed among geographical regions (Fig. 1b, e). Most species were estimated in countries from 

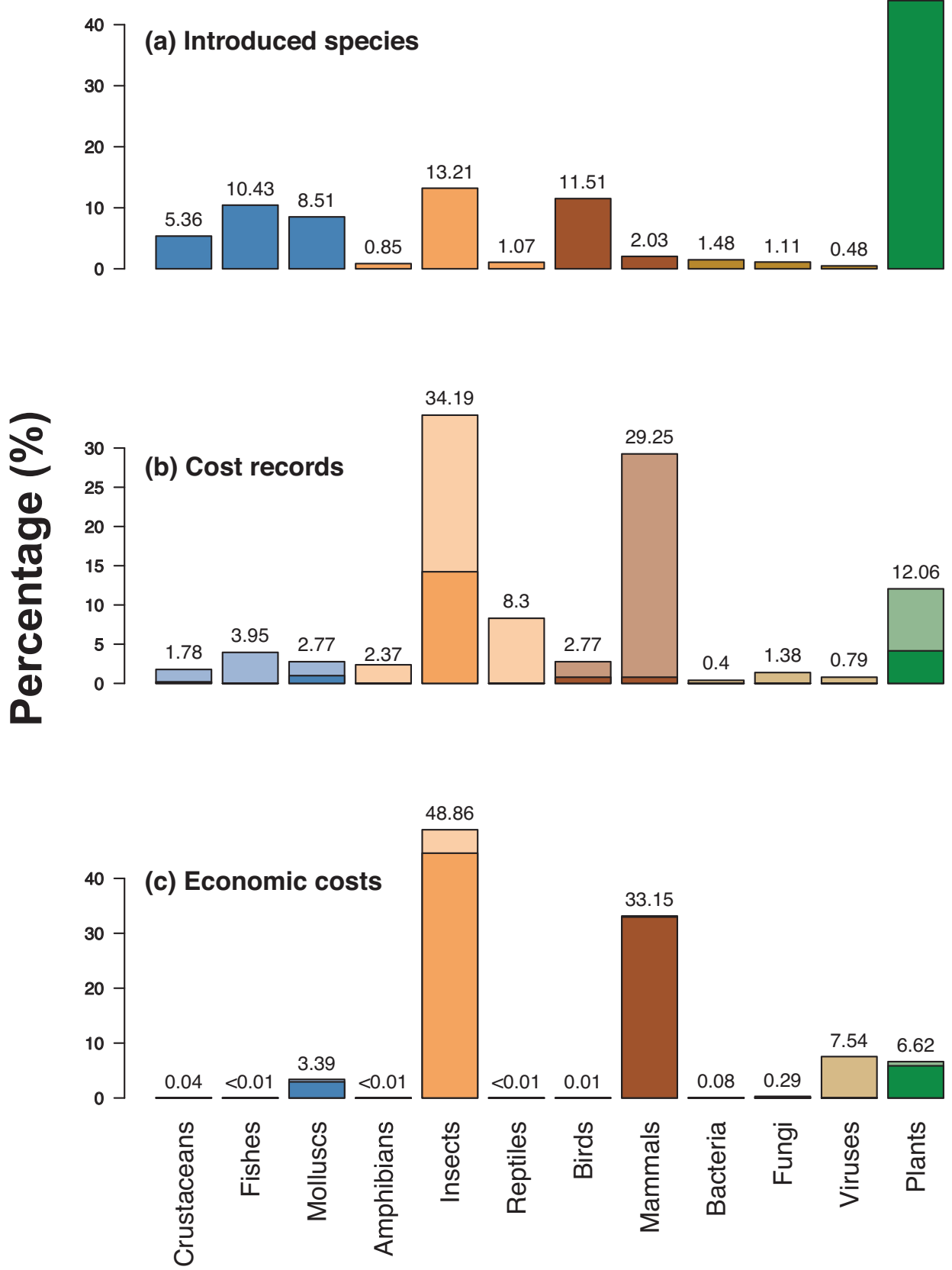

Figure 2. The compositions of (a) species introduced in Asia (b) species with estimated economic costs, and (c) economic costs across 12 taxonomic groups. Data retrieved from English studies are shown in a darker shade and those from non-English studies are in a lighter shade. The percentage of each taxonomic group is shown above the bar. Colors of taxonomic groups correspond to colors of five ecological groups shown in Figure 1. Data of (a) are from the Global Alien Species First Records Database, while data of (b) and (c) from our dataset. 


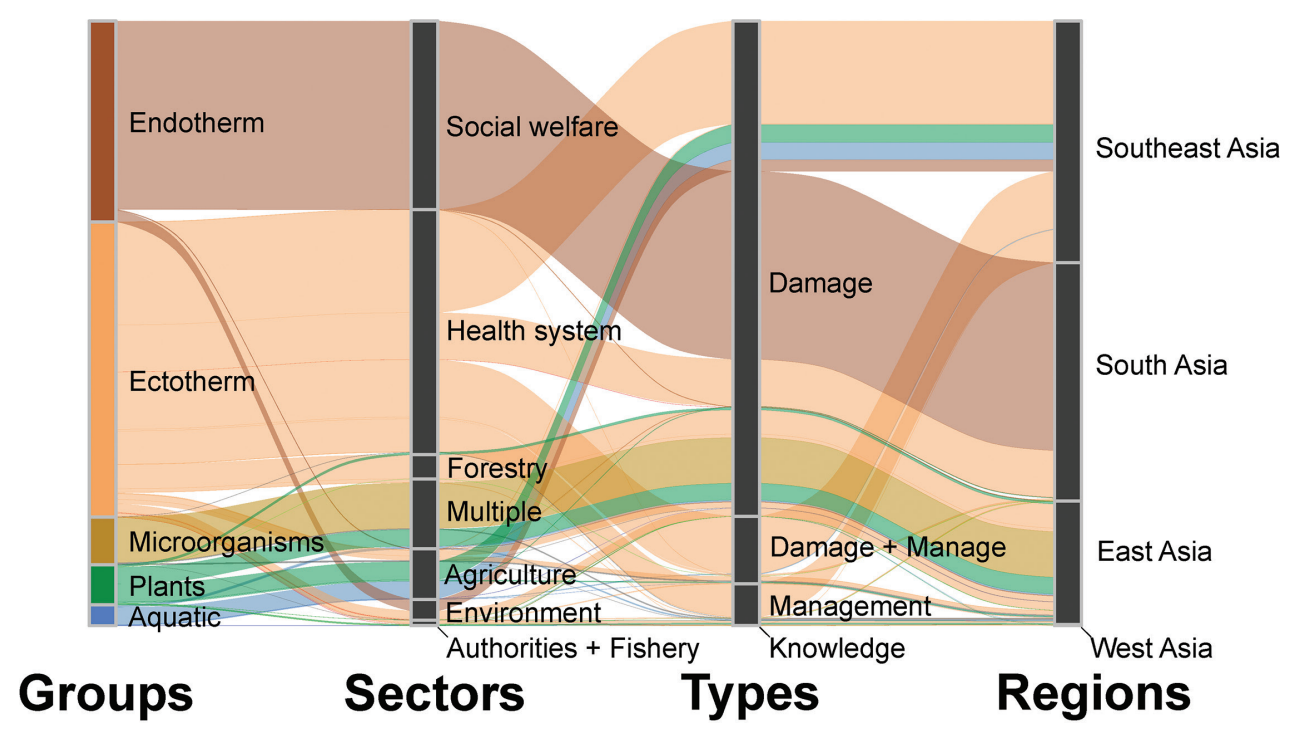

Figure 3. The network showing the composition of economic costs among ecological groups, impacted sectors, types of cost and geographical regions. Only economic costs estimated for particular species were considered, and those estimated for multiple species were excluded. Colors of ecological groups correspond to colors of five ecological groups shown in Figure 1.

East Asia (80.7\%), which was mainly driven by species in Chinese and Japanese studies (74.7\%) (Fig. 1b). Our dataset did not cover records from Central and North Asia (consisting of the Russian regions eastward of the Ural Mountains): data were unavailable for Central Asia, whereas data for North Asia were combined with those from European Russia and no data were specifically reported for North Asia (Kirichenko et al. 2021). Economic costs were highest in South Asia (US\$ 185.8 billion), followed by East Asia (US\$ 175.7 billion), with only US\$ 0.2 billion in Western Asia (Fig. 1e). Similar patterns were was also found among spatial scales (Fig. 1c, f): economic costs at the site level comprised nearly half of records but only contributed to $3.6 \%$ of the total cost, with most of economic costs $(86.1 \%)$ at the country level (Fig. 1f). Economic costs were nearly all estimated at the country $(50.2 \%)$ and site $(47.6 \%)$ levels, with comparatively few $(2.2 \%)$ at the region level (Fig. 1c).

The variations in introduced species, invasive alien species with estimated costs, and amounts of economic costs were also marked among countries (Fig. 4). Around half $(46.9 \%)$ of introduced species were recorded in countries from East Asia, with only $7.1 \%$ in countries from South Asia. Israel was the country with the highest number of introduced species (596), followed by China (560) and Japan (480) (Fig. 4a). However, records of economic costs were heavily driven by Japan (327) and China (113); all other countries, including Israel, had fewer than 10 records (Fig. 4b). Despite only having eight records, India was the country with the highest 

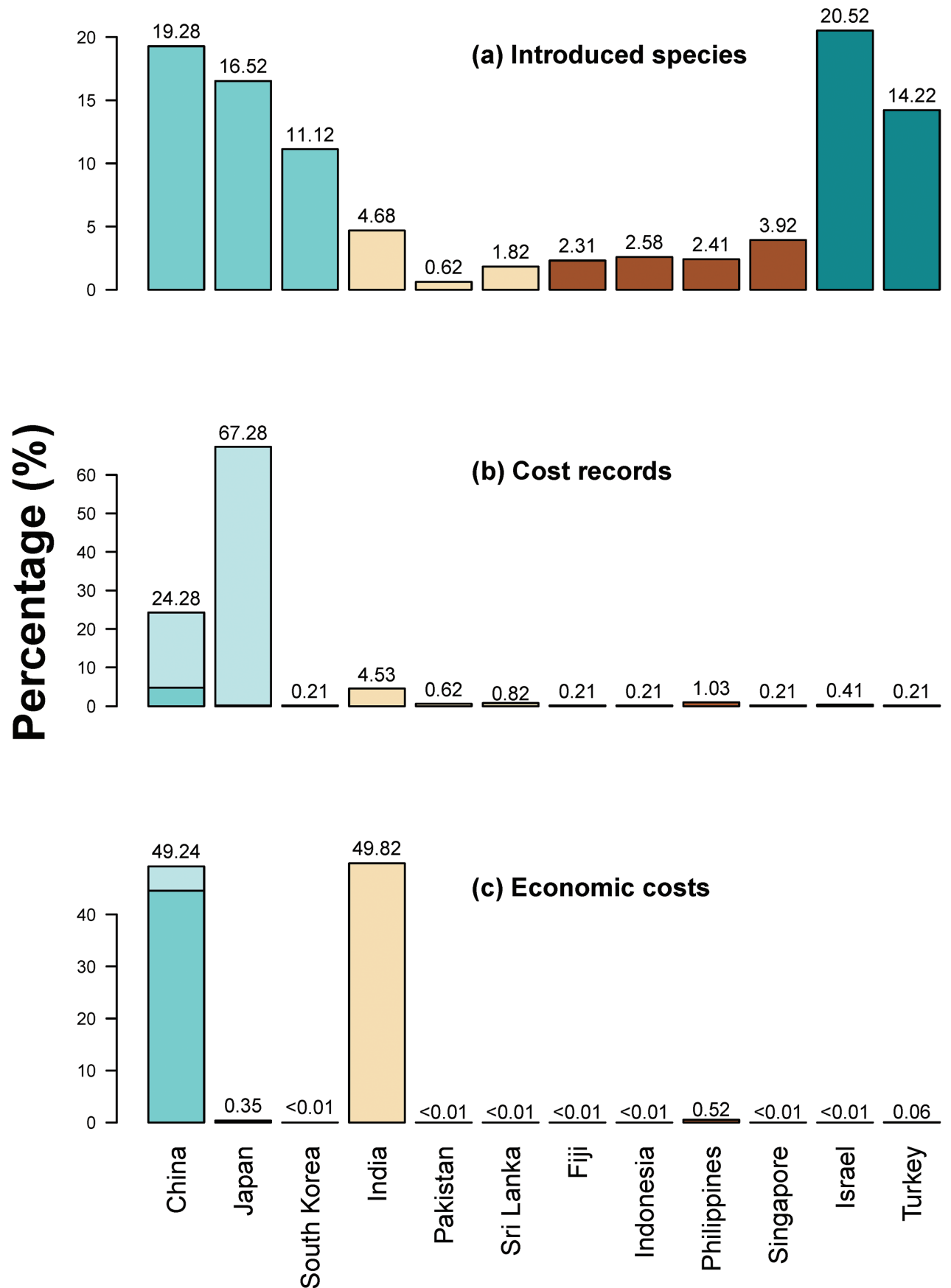

Figure 4. The compositions of (a) species introduced in Asia (b) species with estimated economic costs, and (c) economic costs across 12 countries. Data from English studies are shown in a darker shade and those from non-English studies are in a lighter shade. The percentage of each country is shown above the bar. Colors of countries correspond to colors of four geographical regions shown in Figure 1. Data of (a) are from the Global Alien Species First Records Database, while data of (b) and (c) from our dataset. 


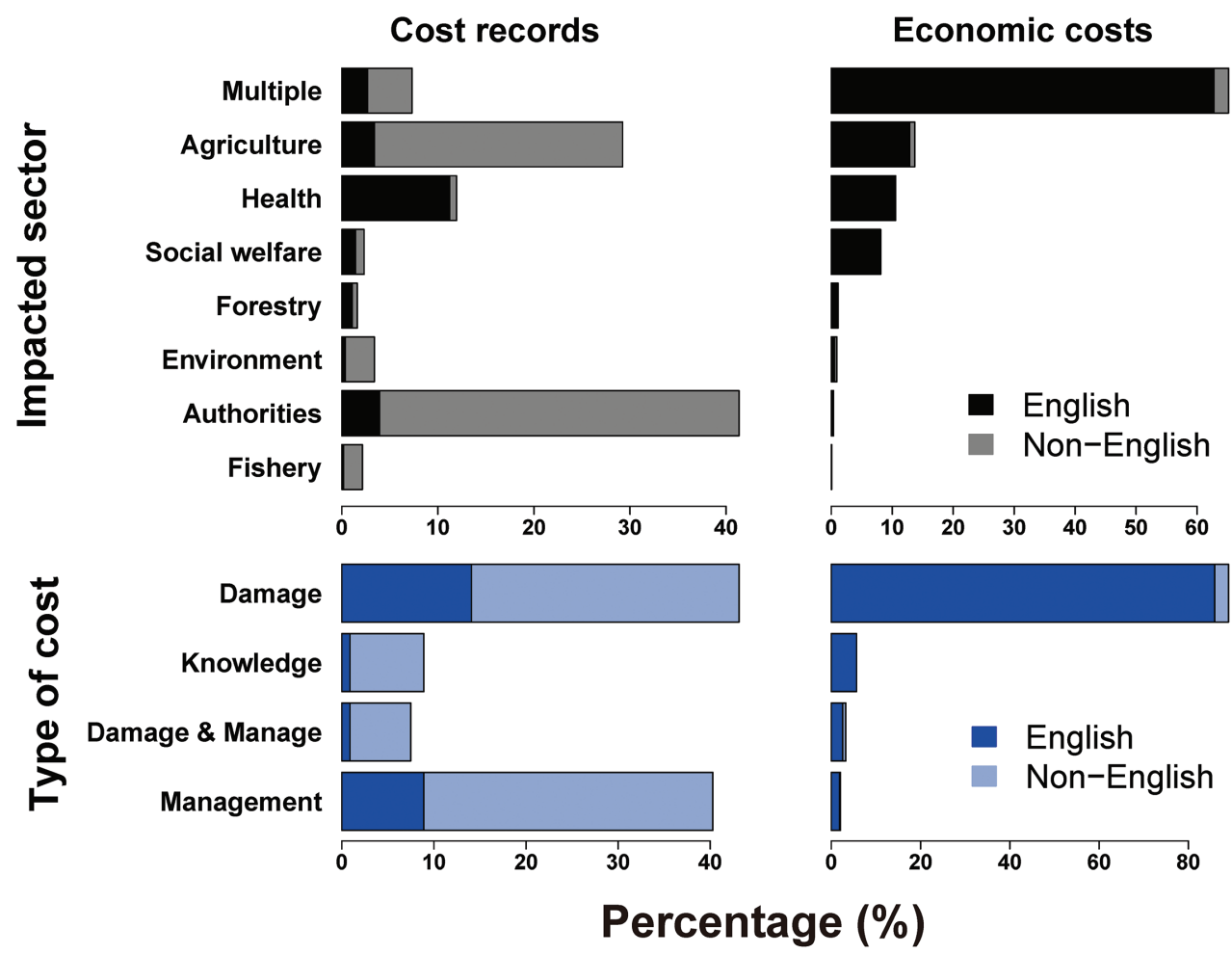

Figure 5. The compositions of records and amounts of economic costs among impacted sectors and types of cost. The categories of impacted sectors and types of costs are ordered according to the amount of economic costs decreasingly. Data from English studies are shown in a darker shade and from non-English studies are in a lighter shade.

economic cost (US\$ 176.7 billion). Economic cost was also very high in China (US\$ 174.7 billion), whereas all other countries contributed to less than $1 \%$ to the total losses (Fig. 4c).

\section{Impacted sectors and types of cost}

There were clear differences in the number of records and economic costs among impacted sectors and types of cost (Fig. 5). Economic costs were most frequently estimated for authorities (41.4\%) and agriculture (29.2\%), but were rarely estimated for social welfare $(2.3 \%)$, fishery $(2.1 \%)$, and forestry $(1.6 \%)$. However, we found that most economic costs $(65.2 \%)$ were related to more than one sector. Agriculture was the specific sector with the highest economic cost (13.7\%), and fishery was the sector with the lowest cost $(0.06 \%)$. Despite the number of records being similar between types of damage (43.1\%) and management (40.3\%), economic costs associated with management were much lower than that of damage ( $2.1 \%$ and $89.0 \%$, respectively). Costs associated with knowledge were also quite low (US\$24.6 billion; 5.7\%). 


\section{Discussion}

Our study synthesized the reported economic impacts of invasive species in Asia and found that the total amount was approximately US\$ 432.6 billion, which is much higher than that recorded in South America (US\$204.0 billion), Oceania (US\$ 180.9 billion), Europe (US\$ 125.6 billion), and Africa (US\$ 18.8 billion) but much lower than that in North America (US\$ 6.1 trillion) (Diagne et al. 2020b). Despite this great figure, economic losses are very likely underestimated across Asia. This is because more than $96 \%$ of known introduced species have not yet been estimated for costs, corroborating a previous assumption that only a very small proportion of invaders have been economically analyzed so far (Aukema et al. 2011). Although not every introduced species can cause impacts in new ranges, previous studies have found that around $30 \%$ of introduced species have been reported with ecological impacts (Measey et al. 2020). As such, we suggest the accumulated economic losses would be inevitably higher if more invaders were estimated, even if their impacts were to be intermediate or even low (Bradshaw et al. 2016; Hanley and Roberts 2019). We also found a clear bias in the number of estimated species and the amount of reported cost across years, suggesting the irregular reporting and improved data accessibility of economic costs of invasive species. For example, the marked increases in the number of estimated species in 2000 and 2013-2016 were driven by the increased data of economic costs reported from Chinese and Japanese references at those times, respectively.

Nevertheless, our study demonstrates the vital importance of considering data from non-English sources in order to have a more completed estimation of economic costs. Non-English data covered all major taxonomic groups of species introduced in Asia and contributed more records than English data, confirming the language barrier in conservation biology (Amano et al. 2016). Despite non-English data contributing more cost records, the total cost of non-English data was much less than that from English data. This finding is probably related to the spatial scale of the English and non-English data. Most of the English records were reported at country level, therefore the cost of English data is inevitably higher than that of non-English data, for which the majority of records were estimated at site level (see Results for more details). Although publishing studies in English has largely facilitated the transfer of scientific knowledge, it remains a big challenge for conservation practitioners and stakeholders for whom English is not the primary language for work and communication (Amano et al. 2016; Nuñez et al. 2019). Most conservation actions at the national level are coordinated in non-English languages in many Asian countries (Nuñez et al. 2019), and the under-representation of national studies might cause biases in scientific information transferred to policy makers and stakeholders in international forums. Despite non-English data being explicitly integrated in the present study, this was insufficiently comprehensive to capture all Asian languages in which invasion costs may be reported. However, India, Russia, China and Japan have been the focus of a more extensive research effort (e.g. local language searches and direct contact with local experts) because: (i) lower income countries often lack resources to conduct national economic analyses (generally in their own language) 
and (ii) NGOs generally write in English and their reports should therefore have been captured by our search and be included in InvaCost. Consequently, even though our non-English data clearly shows the effect of a lower research effort for many Asian countries, we believe our strategy has allowed us to minimize the number of overlooked records. To tackle language barriers, publishers and/or authors could regularly translate non-English studies to English to maximize the accessibility and effectiveness of these studies (Amano et al. 2016; Tao et al. 2018). It is, thus, essential to initiate the collaborations between English and non-English speakers so that scientists could disseminate information that is not available in English. Moreover, non-English speakers could upload the local data to the global database to facilitate the international collaborations.

The lack of information in most Asian countries suggests a strong geographical bias in the estimation of economic costs. One reason for the biased coverage may be the difference in economic activities among countries, because invasion impacts are assumed to be poorly documented in countries with lower income (Nghiem et al. 2013). However, we argue that it is probably not a key determinant, because our study largely lacks data from South Korea (only one 'Unspecified' record), Saudi Arabia (no record), Turkey (no record), Thailand (only records of $A$. aegypti and A. albopictus), and Iran (no record), which are all among the ten countries with the highest GDP in Asia (International Monetary Fund 2019; https://www.imf.org/). Data insufficiency is more marked in Central and North Asia, which covers a large proportion of the territory of Asia and is recognized as a priority area for the management of biological invasions (Turbelin et al. 2017). This geographical bias might be partly diminished after including non-English studies from those countries/regions but would still remain widespread, limiting the capacity to manage invasions at the regional scale (Bellard and Jeschke 2016). In addition, we realize the potential limitation in methods of estimating economic impacts at the country level. For example, despite Pimentel et al. (2001) estimating economic impacts in India with much caution, they still applied a rather simple method which just attributed a fixed proportion (12.6\%) of the loss in all crop productions to invasive species. A standardized method is thus urgently needed to unify the estimation of economic impacts across countries (Hanley and Roberts 2019). The development of a more holistic strategy of invasion management also necessitates the close collaboration of countries, because species invasions are not stopped by political boundaries (Bellard and Jeschke 2016; Early et al. 2016).

The estimation of economic costs is heavily biased towards insects and mammals, despite their smaller proportions of introduced species in Asia. It has been well acknowledged that the estimation of invasion impacts mainly focuses on species for which the impacts can be readily quantified (Wilson et al. 2018; Hanley and Roberts 2019). Compared to other taxa, insects and mammals have caused more severe impacts on health systems and social welfare, which can be easily monetized (Bradshaw et al. 2016; Lodge et al. 2016; Hanley and Roberts 2019). The marked taxonomic biases indicate the urgent need of conducting estimation for species from other taxa, especially for taxa currently with limited data. For example, aquatic invasive species (e.g. algae and molluscs) have caused remarkable changes in community structure and 
ecosystem functioning (Xiong et al. 2015; Anton et al. 2019). Indeed, aquatic species only contributed to $8.5 \%$ of cost records and $3.4 \%$ of total amount of economic losses in Asia, indicating the considerable knowledge gap concerning both freshwater and marine invaders. A similar trend has been found at the global scale, where aquatic invasions have cost US\$ 345 billion in recent decades, but are an order of magnitude lower than terrestrial invasion costs (Cuthbert et al. 2021). One possible reason for this knowledge gap is that current assessment of invasion costs largely ignores the decreased economic value associated with changing biodiversity (e.g. the decrease in the abundance and richness of native species), which is very difficult to estimate (Bradshaw et al. 2016; Lodge et al. 2016). Moreover, invasion costs may be more difficult to observe in submerged environments, or could result from generally fewer assets or research biases compared to terrestrial systems (Cuthbert et al. 2021). Our synthesis does not include any study specifically estimating economic impacts of marine invaders, although countries in Asia produce more than $80 \%$ of all marine cultured biomass (The State of World Fisheries and Aquaculture 2020). Moreover, the opening of the Suez Canal sparked the massive invasions of organisms from the Red Sea to the coast of Israel (Galil et al. 2019). Hence, future studies should not only characterize species with high economic impacts, but also assess the relationship between ecological and economic impacts, given the current information of ecological impacts is much more abundant (Jeschke et al. 2014; Lodge et al. 2016; McGeoch et al. 2016).

Compared to the great damages caused by invaders, the expenditures on management contributed to only $2.3 \%$ of total economic costs in Asia. Management costs were similarly very low in Central and South America (2.1\%, Herigner et al. 2021). In other continents, management expenses were always higher than in Asia, yet consistently much lower than damage and loss costs: Africa (27\%, Diagne et al. 2021), Europe (16\%, Haubrock et al. 2021), or North America (<20\%, Crystal-Ornelas et al. 2021). This suggests the necessity of increasing funding for invasion management in Asia. Although preventing species introduction is the most cost-effective way to manage future invasions (Hulme 2006; Lodge et al. 2016), the majority of Asian countries are still under-equipped to mitigate invasions (Early et al. 2016; Turbelin et al. 2017). The difference in economic costs among impacted sectors echoes the bias among taxonomic groups, with much fewer records being reported for fishery and forestry. Estimating economic impacts is further complicated by the notorious difficulty in some sectors, such as ecosystem-regulating services, for which species impacts depend on recipient contexts and invasion stages (Bradshaw et al. 2016; Lodge et al. 2016; Wilson et al. 2018; Hanley and Roberts 2019). To better inform invasion management, more attention should be paid to estimating sectors currently with limited information.

Invasive species have caused great economic losses in Asia, but we should be aware that reported economic impacts are more related to historical rather than current socioeconomic activities (i.e. invasion debt; Essl et al. 2011): we are now mainly seeing the impacts caused by species that were introduced in the last century, and are yet to endure the impacts of following invasions. In the future, we would expect heightened economic impacts of invasive species in Asia, due to the consequence of considerable 
increases in trade activities and international travel and tourism (Seebens et al. 2017; Sardain et al. 2019). Rapidly changing climates would further facilitate the expansion of invasive species and exaggerate their impacts (Bellard et al. 2013; Hanley and Roberts 2019; Essl et al. 2020). To optimize the allocation of limited resources, the management of invasions should be prioritized towards species causing higher economic impacts and regions suffering higher losses (Vander Zanden and Olden 2008; $\mathrm{McGeoch}$ et al. 2016). We also suggest economic costs should be more comprehensively estimated for species with known environmental impacts, and reported in a centralized and standardized manner to ensure reliable quantifications of impacts at multiple scales. Finally, we call for more collaboration at the national (especially between researchers, stakeholders and decision-makers) and international scales to provide further incentive to estimate economic costs associated with biological invasions in Asia.

\section{Acknowledgements}

We are grateful to Haigen Xu for providing data on economic costs. We want to acknowledge all environmental managers, national officials, practitioners and researchers who kindly answered our request for information about the costs of invasive species. We sincerely thank Darren Yeo, Kit Magellan and two anonymous referees for their constructive comments that significantly improved our manuscript.

The authors acknowledge the French National Research Agency (ANR-14CE02-0021) and the BNP-Paribas Foundation Climate Initiative for funding the InvaCost project that allowed the construction of the InvaCost database. The present work was conducted following a workshop funded by the AXA Research Fund Chair of Invasion Biology and is part of the AlienScenario project funded by BiodivERsA and Belmont-Forum call 2018 on biodiversity scenarios. CL was sponsored by the PRIME programme of the German Academic Exchange Service (DAAD) with funds from the German Federal Ministry of Education and Research (BMBF). NK was partially supported by the basic project of Sukachev Institute of Forest SB RAS (project No. 02872021-0011) [national literature survey], the Russian Foundation for Basic Research (project No. 19-04-01029-A) [InvaCost database contribution] and the Ministry of Education and Science of the Russian Federation (project No. FEFE-2020-0014) [data analysis]. RC acknowledges funding from the Alexander von Humboldt Foundation. $\mathrm{CD}$ was funded by the BiodivERsA-Belmont Forum Project "AlienScenarios" (BMBF/ PT DLR 01LC1807C). Funds for EA contract come from the AXA Research Fund Chair of Invasion Biology of University Paris Saclay.

\section{References}

Angulo E, Diagne C, Ballesteros-Mejia L, Adamjy T, Ahmed DA, Akulov E, Banerjee AK, Capinha C, Dia CAKM, Dobigny G, Duboscq-Carra VG, Golivets M, Haubrock PJ, 
Heringer G, Kirichenko N, Kourantidou M, Liu C, Nuñez MA, Renault D, Roiz D, Taheri A, Verbrugge L, Watari Y, Xiong W, Courchamp F (2021) Non-English languages enrich scientific data: the example of the costs of biological invasions. Science of the Total Environment 775: e144441. https://doi.org/10.1016/j.scitotenv.2020.144441

Amano T, González-Varo JP, Sutherland WJ (2016) Languages are still a major barrier to global science. PLoS Biology 14: e2000933. https://doi.org/10.1371/journal.pbio.2000933

Anton A, Geraldi NR, Lovelock CE, Apostolaki ET, Bennett S, Cebrian J, Krause-Jensen D, Marbà N, Martinetto P, Pandolfi JM, Santana-Garcon J, Duarte CM (2019) Global ecological impacts of marine exotic species. Nature Ecology \& Evolution 3: 787-800. https:// doi.org/10.1038/s41559-019-0851-0

Aukema JE, Leung B, Kovacs K, Chivers C, Britton KO, Englin J, Frankel SJ, Haight RG, Holmes TP, Liebhold AM, McCullough DG, von Holle B (2011) Economic impacts of non-native forest insects in the continental United States. PLoS ONE 6: 1-7. https://doi. org/10.1371/journal.pone.0024587

Bellard C, Jeschke JMM (2016) A spatial mismatch between invader impacts and research publications. Conservation Biology 30: 230-232. https://doi.org/10.1111/cobi.12611

Bellard C, Thuiller W, Leroy B, Genovesi P, Bakkenes M, Courchamp F (2013) Will climate change promote future invasions? Global Change Biology 19: 3740-3748. https://doi. org/10.1111/gcb.12344

Bradshaw CJA, Leroy B, Bellard C, Roiz D, Albert C, Fournier A, Barbet-Massin M, Salles J-M, Simard F, Courchamp F (2016) Massive yet grossly underestimated global costs of invasive insects. Nature Communications 7: e12986. https://doi.org/10.1038/ncomms12986

Crystal-Ornelas R, Hudgins EJ, Cuthbert RN, Haubrock PJ, Fantle-Lepczyk J, Angulo E, Kramer AM, Ballesteros-Mejia L, Leroy B, Leung B, López-López E, Diagne C, Courchamp F (2021) Economic costs of biological invasions within North America. In: Zenni RD, McDermott S, García-Berthou E, Essl F (Eds) The economic costs of biological invasions around the world. NeoBiota 67: 485-510. https://doi.org/10.3897/neobiota.67.58038

Cuthbert RN, Bacher S, Blackburn TM, Briski E, Diagne C, Dick JTA, Essl F, Genovesi P, Haubrock PJ, Latombe G, Lenzner B, Meinard Y, Pauchard A, Pyšek P, Ricciardi A, Richardson DM, Russell JC, Simberloff D, Courchamp F (2020) Invasion costs, impacts, and human agency: response to Sagoff 2020. Conservation Biology 34: 1579-1582. https:// doi.org/10.1111/cobi.13592

Cuthbert RN, Pattison Z, Taylor NG, Verbrugge L, Diagne C, Ahmed DA, Leroy B, Angulo E, Briski E, Capinha C, Catford JA, Dalu T, Essl F, Gozlan RE, Haubrock PJ, Kourantidou M, Kramer AM, Renault D, Wasserman RJ, Courchamp F (2021) Global economic costs of aquatic invasive alien species. Science of the Total Environment 775: e145238. https:// doi.org/10.1016/j.scitotenv.2021.145238

Diagne C, Catford JA, Essl F, Nuñez MA, Courchamp F (2020a) What are the economic costs of biological invasions? A complex topic requiring international and interdisciplinary expertise. NeoBiota 63: 25-37. https://doi.org/10.3897/neobiota.63.55260

Diagne C, Leroy B, Gozlan RE, Vaissière A-C, Assailly C, Nuninger L, Roiz D, Jourdain F, Jarić I, Courchamp F (2020b) InvaCost, a public database of the economic costs of biological invasions worldwide. Scientific Data 7: e277. https://doi.org/10.1038/s41597-020-00586-z 
Diagne C, Turbelin AJ, Moodley D, Novoa A, Leroy B, Angulo E, Adamjy T, Dia CAKM, Taheri A, Tambo J, Dobigny G, Courchamp F (2021) The economic costs of biological invasions in Africa: a growing but neglected threat? In: Zenni RD, McDermott S, GarcíaBerthou E, Essl F (Eds) The economic costs of biological invasions around the world. NeoBiota 67: 11-51. https://doi.org/10.3897/neobiota.67.59132

Ding J, Mack RN, Lu P, Ren M, Huang H (2008) China's booming economy is sparking and accelerating biological invasions. BioScience 58: 317-324. https://doi.org/10.1641/B580407

Early R, Bradley BA, Dukes JS, Lawler JJ, Olden JD, Blumenthal DM, Gonzalez P, Grosholz ED, Ibañez I, Miller LP, Sorte CJBB, Tatem AJ (2016) Global threats from invasive alien species in the twenty-first century and national response capacities. Nature Communications 7: e12485. https://doi.org/10.1038/ncomms12485

Essl F, Dullinger S, Rabitsch W, Hulme PE, Hulber K, Jarosik V, Kleinbauer I, Krausmann F, Kuhn I, Nentwig W, Vila M, Genovesi P, Gherardi F, Desprez-Loustau MLM-L, Roques A, Pyšek P (2011) Socioeconomic legacy yields an invasion debt. Proceedings of the National Academy of Sciences 108: 203-207. https://doi.org/10.1073/pnas.1011728108

Essl F, Lenzner B, Bacher S, Bailey S, Capinha C, Daehler C, Dullinger S, Genovesi P, Hui C, Hulme PE, Jeschke JM, Katsanevakis S, Kühn I, Leung B, Liebhold A, Liu C, MacIsaac HJ, Meyerson LA, Nuñez MA, Pauchard A, Pyšek P, Rabitsch W, Richardson DM, Roy HE, Ruiz GM, Russell JC, Sanders NJ, Sax DF, Scalera R, Seebens H, Springborn M, Turbelin A, Kleunen M, Holle B, Winter M, Zenni RD, Mattsson BJ, Roura-Pascual N (2020) Drivers of future alien species impacts: An expert-based assessment. Global Change Biology 26: 4880-4893. https://doi.org/10.1111/gcb.15199

Galil BS, Danovaro R, Rothman SBS, Gevili R, Goren M (2019) Invasive biota in the deepsea Mediterranean: an emerging issue in marine conservation and management. Biological Invasions 21: 281-288. https://doi.org/10.1007/s10530-018-1826-9

Hanley N, Roberts M (2019) The economic benefits of invasive species management. People and Nature 1: 124-137. https://doi.org/10.1002/pan3.31

Haubrock PJ, Cuthbert RN, Sundermann A, Diagne C, Golivets M, Courchamp F (2021) Economic costs of invasive species in Germany. In: Zenni RD, McDermott S, GarcíaBerthou E, Essl F (Eds) The economic costs of biological invasions around the world. NeoBiota 67: 225-246. https://doi.org/10.3897/neobiota.67.59502

Heringer G, Angulo E, Ballesteros-Mejia L, Capinha C, Courchamp F, Diagne C, DuboscqCarra VG, Nuñez MA, Zenni RD (2021) The economic costs of biological invasions in Central and South America: a first regional assessment. In: Zenni RD, McDermott S, García-Berthou E, Essl F (Eds) The economic costs of biological invasions around the world. NeoBiota 67: 401-426. https://doi.org/10.3897/neobiota.67.59193

Hulme PE (2006) Beyond control: Wider implications for the management of biological invasions. Journal of Applied Ecology 43: 835-847. https://doi.org/10.1111/j.13652664.2006.01227.x

Jeschke JM, Bacher S, Blackburn TM, Dick JTA, Essl F, Evans T, Gaertner M, Hulme PE, Kühn I, Mrugała A, Pergl J, Pyšek P, Rabitsch W, Ricciardi A, Richardson DM, Sendek A, Vilà M, Winter M, Kumschick S (2014) Defining the impact of non-native species. Conservation Biology 28: 1188-1194. https://doi.org/10.1111/cobi.12299 
Ju R, Li X, Jiang J, Wu J, Liu J, Strong DR, Li B (2019) Emerging risks of non-native species escapes from aquaculture: call for policy improvements in China and other developing countries. Journal of Applied Ecology 57(1): 85-90. https://doi.org/10.1111/1365-2664.13521

Kirichenko N, Haubrock PJ, Cuthbert RN, Akulov E, Karimova E, Shneyder Y, Liu C, Angulo E, Diagne C, Courchamp F (2021) Economic costs of biological invasions in terrestrial ecosystems in Russia. In: Zenni RD, McDermott S, García-Berthou E, Essl F (Eds) The economic costs of biological invasions around the world. NeoBiota 67: 103-130. https:// doi.org/10.3897/neobiota.67.58529

Konno K, Akasaka M, Koshida C, Katayama N, Osada N, Spake R, Amano T (2020) Ignoring non-English-language studies may bias ecological meta-analyses. Ecology and Evolution 10(13): 6373-6384. https://doi.org/10.1002/ece3.6368

Liu C, He D, Chen Y, Olden JD (2017) Species invasions threaten the antiquity of China's freshwater fish fauna. Diversity and Distributions 23: 556-566. https://doi.org/10.1111/ ddi. 12541

Liu X, McGarrity ME, Li Y (2012) The influence of traditional Buddhist wildlife release on biological invasions. Conservation Letters 5: 107-114. https://doi.org/10.1111/j.1755263X.2011.00215.x

Lodge DM, Simonin PW, Burgiel SW, Keller RP, Bossenbroek JM, Jerde CL, Kramer AM, Rutherford ES, Barnes MA, Wittmann ME, Chadderton WL, Apriesnig JL, Beletsky D, Cooke RM, Drake JM, Egan SP, Finnoff DC, Gantz CA, Grey EK, Hoff MH, Howeth JG, Jensen RA, Larson ER, Mandrak NE, Mason DM, Martinez FA, Newcomb TJ, Rothlisberger JD, Tucker AJ, Warziniack TW, Zhang H (2016) Risk analysis and bioeconomics of invasive species to inform policy and management. Annual Review of Environment and Resources 41: 453-488. https://doi.org/10.1146/annurev-environ-110615-085532

McGeoch MA, Genovesi P, Bellingham PJ, Costello MJ, McGrannachan C, Sheppard A (2016) Prioritizing species, pathways, and sites to achieve conservation targets for biological invasion. Biological Invasions 18: 299-314. https://doi.org/10.1007/s10530-015-1013-1

Measey J, Wagener C, Mohanty NP, Baxter-Gilbert J, Pienaar EF (2020) The cost and complexity of assessing impact. NeoBiota 62: 279-299. https://doi.org/10.3897/neobiota.62.52261 Nghiem LTP, Soliman T, Yeo DCJ, Tan HTW, Evans TA, Mumford JD, Keller RP, Baker RHA, Corlett RT, Carrasco LR (2013) Economic and environmental impacts of harmful nonindigenous species in Southeast Asia. PLoS ONE 8(8): e71255. https://doi.org/10.1371/ journal.pone.0071255

Nunes AL, Fill JM, Davies SJ, Louw M, Rebelo AD, Thorp CJ, Vimercati G, Measey J (2019) A global meta-analysis of the ecological impacts of alien species on native amphibians. Proceedings of the Royal Society B: Biological Sciences 286(1897): 1-10. https://doi. org/10.1098/rspb.2018.2528

Nuñez MA, Barlow J, Cadotte M, Lucas K, Newton E, Pettorelli N, Stephens PA (2019) Assessing the uneven global distribution of readership, submissions and publications in applied ecology: obvious problems without obvious solutions. Journal of Applied Ecology 56: 4-9. https://doi.org/10.1111/1365-2664.13319

Paini DR, Sheppard AW, Cook DC, De Barro PJ, Worner SP, Thomas MB (2016) Global threat to agriculture from invasive species. Proceedings of the National Academy of Sciences of the United States of America 113: 7575-7579. https://doi.org/10.1073/pnas.1602205113 
Pimentel D, McNair S, Janecka J, Wightman J, Simmonds C, O’Connell C, Wong E, Russel L, Zern J, Aquino T, Tsomondo T (2001) Economic and environmental threats of alien plant, animal, and microbe invasions. Agriculture, Ecosystems and Environment 84: 1-20. https://doi.org/10.1016/S0167-8809(00)00178-X

Sardain A, Sardain E, Leung B (2019) Global forecasts of shipping traffic and biological invasions to 2050. Nature Sustainability 2: 274-282. https://doi.org/10.1038/s41893-019-0245-y

Seebens H, Blackburn TM, Dyer EE, Genovesi P, Hulme PE, Jeschke JM, Pagad S, Pyšek P, Winter M, Arianoutsou M, Bacher S, Blasius B, Brundu G, Capinha C, Celesti-Grapow L, Dawson W, Dullinger S, Fuentes N, Jäger H, Kartesz J, Kenis M, Kreft H, Kühn I, Lenzner B, Liebhold A, Mosena A, Moser D, Nishino M, Pearman D, Pergl J, Rabitsch W, RojasSandoval J, Roques A, Rorke S, Rossinelli S, Roy HE, Scalera R, Schindler S, Štajerová K, Tokarska-Guzik B, van Kleunen M, Walker K, Weigelt P, Yamanaka T, Essl F (2017) No saturation in the accumulation of alien species worldwide. Nature Communications 8: e14435. https://doi.org/10.1038/ncomms14435

Seebens H, Blackburn TM, Dyer EE, Genovesi P, Hulme PE, Jeschke JM, Pagad S, Pyšek P, van Kleunen M, Winter M, Ansong M, Arianoutsou M, Bacher S, Blasius B, Brockerhoff EG, Brundu G, Capinha C, Causton CE, Celesti-Grapow L, Dawson W, Dullinger S, Economo EP, Fuentes N, Guénard B, Jäger H, Kartesz J, Kenis M, Kühn I, Lenzner B, Liebhold AM, Mosena A, Moser D, Nentwig W, Nishino M, Pearman D, Pergl J, Rabitsch W, Rojas-Sandoval J, Roques A, Rorke S, Rossinelli S, Roy HE, Scalera R, Schindler S, Štajerová K, Tokarska-Guzik B, Walker K, Ward DF, Yamanaka T, Essl F (2018) Global rise in emerging alien species results from increased accessibility of new source pools. Proceedings of the National Academy of Sciences 115: E2264-E2273. https://doi.org/10.1073/pnas.1719429115

Shepard DS, Undurraga EA, Halasa YA (2013) Economic and disease burden of dengue in Southeast Asia. PLoS Neglected Tropical Diseases 7: e2055. https://doi.org/10.1371/journal.pntd.0002055

Tao J, Ding C, Ho YS (2018) Publish translations of Chinese papers. Nature 557: 492-492. https://doi.org/10.1038/d41586-018-05235-5

Turbelin AJ, Malamud BD, Francis RA (2017) Mapping the global state of invasive alien species: patterns of invasion and policy responses. Global Ecology and Biogeography 26: 78-92. https://doi.org/10.1111/geb.12517

Twardochleb LA, Olden JD, Larson ER (2013) A global meta-analysis of the ecological impacts of nonnative crayfish. Freshwater Science 32: 1367-1382. https://doi.org/10.1899/12-203.1

Vilà M, Espinar JL, Hejda M, Hulme PE, Jarošík V, Maron JL, Pergl J, Schaffner U, Sun Y, Pyšek P (2011) Ecological impacts of invasive alien plants: a meta-analysis of their effects on species, communities and ecosystems. Ecology Letters 14: 702-708. https://doi. org/10.1111/j.1461-0248.2011.01628.x

Wang H, Xie D, Bowler PA, Zeng Z, Xiong W, Liu C (2020) Non-indigenous species in marine and coastal habitats of the South China Sea. Science of The Total Environment 95: e143465. https://doi.org/10.1016/j.scitotenv.2020.143465

Watari Y, Komine H, Angulo E, Diagne C, Ballesteros-Mejia L, Courchamp F (2021) First synthesis of the economic costs of biological invasions in Japan. In: Zenni RD, McDermott S, García-Berthou E, Essl F (Eds) The economic costs of biological invasions around the world. NeoBiota 67: 79-101. https://doi.org/10.3897/neobiota.67.59186 
Wilson JRU, Faulkner KT, Rahlao SJ, Richardson DM, Zengeya TA, Wilgen BW (2018) Indicators for monitoring biological invasions at a national level. Journal of Applied Ecology 55: 2612-2620. https://doi.org/10.1111/1365-2664.13251

Xiong W, Sui X, Liang S-H, Chen Y (2015) Non-native freshwater fish species in China. Reviews in Fish Biology and Fisheries 25: 651-687. https://doi.org/10.1007/s11160-015-9396-8

Xu H, Ding H, Li M, Qiang S, Guo J, Han Z, Huang Z, Sun H, He S, Wu H, Wan F (2006) The distribution and economic losses of alien species invasion to China. Biological Invasions 8: 1495-1500. https://doi.org/10.1007/s10530-005-5841-2

Vander Zanden MJ, Olden JD (2008) A management framework for preventing the secondary spread of aquatic invasive species. Canadian Journal of Fisheries and Aquatic Sciences 65: 1512-1522. https://doi.org/10.1139/F08-099

\section{Supplementary material I}

Table S1. The dataset of economic costs caused by invasive species in Asia Authors: Chunlong Liu, Christophe Diagne, Elena Angulo, Achyut-Kumar Banerjee, Yifeng Chen, Ross N. Cuthbert, Phillip J. Haubrock, Natalia Kirichenko, Zarah Pattison, Yuya Watari, Wen Xiong, Franck Courchamp

Data type: database

Copyright notice: This dataset is made available under the Open Database License (http://opendatacommons.org/licenses/odbl/1.0/). The Open Database License $(\mathrm{ODbL})$ is a license agreement intended to allow users to freely share, modify, and use this Dataset while maintaining this same freedom for others, provided that the original source and author(s) are credited.

Link: https://doi.org/10.3897/neobiota.67.58147.suppl1

\section{Supplementary material 2}

Table S2. The classification and description of seven sectors impacted by invasive species

Authors: Chunlong Liu, Christophe Diagne, Elena Angulo, Achyut-Kumar Banerjee, Yifeng Chen, Ross N. Cuthbert, Phillip J. Haubrock, Natalia Kirichenko, Zarah Pattison, Yuya Watari, Wen Xiong, Franck Courchamp

Data type: species data

Copyright notice: This dataset is made available under the Open Database License (http://opendatacommons.org/licenses/odbl/1.0/). The Open Database License $(\mathrm{ODbL})$ is a license agreement intended to allow users to freely share, modify, and use this Dataset while maintaining this same freedom for others, provided that the original source and author(s) are credited.

Link: https://doi.org/10.3897/neobiota.67.58147.suppl2 


\section{Supplementary material 3}

Table S3. The classification and description of four types of costs caused by invasive species

Authors: Chunlong Liu, Christophe Diagne, Elena Angulo, Achyut-Kumar Banerjee, Yifeng Chen, Ross N. Cuthbert, Phillip J. Haubrock, Natalia Kirichenko, Zarah Pattison, Yuya Watari, Wen Xiong, Franck Courchamp

Data type: species data

Copyright notice: This dataset is made available under the Open Database License (http://opendatacommons.org/licenses/odbl/1.0/). The Open Database License $(\mathrm{ODbL})$ is a license agreement intended to allow users to freely share, modify, and use this Dataset while maintaining this same freedom for others, provided that the original source and author(s) are credited.

Link: https://doi.org/10.3897/neobiota.67.58147.suppl3

\section{Supplementary material 4}

Table S4. The completeness of cost estimation for each of five ecological groups per country

Authors: Chunlong Liu, Christophe Diagne, Elena Angulo, Achyut-Kumar Banerjee, Yifeng Chen, Ross N. Cuthbert, Phillip J. Haubrock, Natalia Kirichenko, Zarah Pattison, Yuya Watari, Wen Xiong, Franck Courchamp

Data type: species data

Copyright notice: This dataset is made available under the Open Database License (http://opendatacommons.org/licenses/odbl/1.0/). The Open Database License $(\mathrm{ODbL})$ is a license agreement intended to allow users to freely share, modify, and use this Dataset while maintaining this same freedom for others, provided that the original source and author(s) are credited.

Link: https://doi.org/10.3897/neobiota.67.58147.suppl4 


\section{Supplementary material 5}

Table S5. Species that have been introduced in Asia and caused economic costs in other continents

Authors: Chunlong Liu, Christophe Diagne, Elena Angulo, Achyut-Kumar Banerjee, Yifeng Chen, Ross N. Cuthbert, Phillip J. Haubrock, Natalia Kirichenko, Zarah Pattison, Yuya Watari, Wen Xiong, Franck Courchamp

Data type: species data

Explanation note: Species are ordered according to the amount of economic cost decreasingly.

Copyright notice: This dataset is made available under the Open Database License (http://opendatacommons.org/licenses/odbl/1.0/). The Open Database License $(\mathrm{ODbL})$ is a license agreement intended to allow users to freely share, modify, and use this Dataset while maintaining this same freedom for others, provided that the original source and author(s) are credited.

Link: https://doi.org/10.3897/neobiota.67.58147.suppl5 